\title{
Genetic and nongenetic factors affecting on-farm performance of peri-urban dairy cattle in west Africa
}

\section{Regina Roessler, ${ }^{*}$ Serge E. Mpouam, and Eva Schlecht}

Group Animal Husbandry in the Tropics and Subtropics, University of Kassel and University of Goettingen, 37213 Witzenhausen, Germany

\section{ABSTRACT}

Population growth and urbanization lead to an increasing demand for milk in sub-Saharan Africa, but the production potential of the 65.9 million dairy cows in the region is far from being fully exploited to meet this demand. With the aim to support decision-making for breeding and management of dairy cattle in commercial farms, we performed a comparative study of daily milk offtake, chemical composition of milk, prevalence of metabolic disorders, and body weight development of local and crossbred cattle genotypes in peri-urban commercial farms in Ouagadougou, Burkina Faso. We used data that were collected during regular visits of 7 farms in peri-urban areas of the city over a 16-mo period. Animals belonged to 3 breed groups (123 local zebu, 49 Sahelian crossbred, and 42 European crossbred cows). We applied a mixed model approach to evaluate the genetic and seasonal effects on daily milk offtake, milk composition, and body weight. Nonlinear growth models were fitted to model the body weight development according to genotype, season, and reproductive status of cows. The milk fat-to-milk protein ratio was used to determine the prevalence of ketosis and acidosis. Daily milk offtake from crossbred cows was 3.1- to 4.3-fold higher than from local zebu cows; furthermore, crossbred cows had a higher body weight and maturity rate than local zebu cows. In contrast, no genotype differences were found in milk fat and milk protein percentage and prevalence of ketosis and acidosis. Additionally, seasonal effects suggested that higher production performances could be realized through improved management of dairy cows, particularly in the late dry and rainy season. Improved feeding management could also reduce the risk of metabolic disorders. In summary, production performances of crossbred dairy cows in peri-urban production systems in Burkina Faso are higher as compared with local zebu cows. However, environmental effects suggest

Received July 9, 2018.

Accepted November 10, 2018.

*Corresponding author: regina.roessler@uni-kassel.de that further studies are needed to systematically assess genotype by environment interactions to guide the development of sustainable breeding and management programs for dairy cattle in Burkina Faso.

Key words: crossbreeding, dairy cow, production performance, sub-Saharan Africa

\section{INTRODUCTION}

Urbanization is one of the main challenges faced globally in the 21st century. According to a report of the United Nations on drivers of migration and urbanization in Africa, the share of the global population living in urban areas will increase to $75 \%$ by 2050 , with subSaharan Africa (SSA) being one of the fastest urbanizing regions (Awumbila, 2017). Urban centers currently generate half of the gross domestic product in SSA, and they will play a pivotal role in sustaining economic growth in the region (Saghir and Santoro, 2018). Due to urbanization and higher income levels, it is projected that SSA will experience the second highest growth in milk consumption after China (3.3\% annually), representing a growing market opportunity for local producers, particularly in urban areas (Staal, 2001). In 2016, the total number of dairy cows in SSA was estimated at 65.9 million, producing 29.1 million tonnes of milk (FAOSTAT, 2016). However, although the local dairy sector is well established in east Africa, with Kenya, Ethiopia, Sudan, and South Sudan representing 47\% of the total milk production in SSA (FAOSTAT, 2016), the import dependency for dairy products averages $90 \%$ in west and central Africa (Goodison, 2015) because the milk production potential is not fully exploited. However, an intensification of the local dairy sector can be witnessed in some West African countries, such as Mali (Amadou et al., 2012), Burkina Faso (Amadou et al., 2012; Roessler et al., 2016), and Nigeria (Saleh et al., 2016). The intensification and modernization of the dairy sector in SSA is commonly associated with a combination of genetically improved cattle genotypes that are used to upgrade local cows, as well as concentrate feeding and to grazing to increase milk production (Gnanda et al., 2016; Saleh et al., 2016). However, 
it has been shown that crossbreeding with imported breeds and higher inputs in livestock systems, particularly into feeding, do not necessarily lead to higher production output (Roessler et al., 2016). This can be explained by low milk yields of crossbred cows on dairy farms in SSA that do not respond to higher production input. For example, the daily milk production of exotic crossbred cows in Burkina Faso and Nigeria was estimated at 7.5 (Gnanda et al., 2016) and $8.8 \mathrm{~L}$ (Saleh et al., 2016), respectively. At the same time, we estimated that 74 and $33 \%$ of the cows in dairy farms in Ouagadougou (Burkina Faso) suffered energy over- and undersupply at least during part of the year, respectively, and the situation for protein supply was similar [E. Schlecht, J. Plagemann (University of Kassel and University of Goettingen), S. E. Mpouam, H. O. Sanon (Institut de l'Environnement et de Recherches Agricoles, Ouagadougou, Burkina Faso), M. Sangaré (Centre International de Recherche-Développement sur l'Elevage en zone Subhumide, Bob-Dioulasso, Burkina Faso), and R. Roessler, unpublished data]. Unbalanced provision of energy and protein can lead to metabolic disorders such as ketosis and acidosis and lower the milk yield of improved genotypes, thereby further increasing production costs. Taken together, the available studies indicate that the genetic potential of crossbred cows is not fully exploited due to extreme climatic conditions and variable quantity and quality of feed resources in SSA. Hence, it is imperative to better understand the genotype by environment interactions to identify appropriate genotypes and to further optimize dairy production systems in western SSA to keep pace with the growing demand for dairy products in the region.

The purpose of the present study was to systematically assess genetic and nongenetic factors that affect daily milk offtake (milk used for human consumption, excluding milk consumed by the calf), milk composition, and occurrence of metabolic disorders in cows, as well as weight development of female replacement stock on dairy farms in Ouagadougou, Burkina Faso. We defined genetic factors as those attributable to a specific breed group. Our aim was to identify genotypes that are adapted to the prevailing production conditions on commercial dairy farms and to provide information for the design of effective selection and breeding systems for the dairy production sector in Burkina Faso.

\section{MATERIALS AND METHODS}

\section{Data}

Records used for the present study were extracted from the animal performance database of the livestock subproject of the UrbanFood ${ }^{\text {Plus }}$ project (http://www .urbanfoodplus.org/index.php?id = 5), which has been implemented in Ouagadougou, Burkina Faso. Ouagadougou is the capital city of Burkina Faso, a landlocked country in the Sudano-Sahelian zone of western SSA. Its population is estimated at more than 2.7 million (United Nations, 2016). The climate in Ouagadougou is classified as steppe after Köppen and Geiger (Peel et al., 2007) and averages an annual temperature of $28.2^{\circ} \mathrm{C}$ (www.climate-data.org). During the study period, highest average temperatures were reached in April $\left(40^{\circ} \mathrm{C}\right)$ and lowest average temperatures occurred in February $\left(14^{\circ} \mathrm{C}\right)$. The rainy season is relatively short and usually lasts from May until mid-October. Annual rainfalls amounted to 731 (2014) and $821 \mathrm{~mm}$ (2015; R. Roessler, S. E. Mpouam, and E. Schlecht, unpublished data).

The database comprises on-farm monitoring data collected in 7 household farms over a period of 16 mo (from October 2014 until February 2016). Each household farm was visited 10 times, in intervals of 6 to $10 \mathrm{wk}$. The predominant breed was the local zebu Peul, which was reared on 6 of the 7 farms. Crossbreds between the local zebu and Sahelian/transboundary zebu breeds (Azawak, Bororo, Gudali) or various European/international cattle breeds, namely Holstein, Montbéliarde, Tarentaise, and Brown Swiss, were found on 4 and 3 farms, respectively. Three farms exclusively reared the local zebu, whereas 2 farms had all 3 types of cattle. The genetic composition and exact gene proportions of the crossbred cows were unknown. The average herd size on the farms was 32.2 cattle $($ minimum $=13.5$, maximum $=67.7)$, of which 16.8 lactating and dry cows (minimum $=7.8$, maximum $=34.9$ ). The number of female cattle by breed group averaged 20.5 (local zebu), 12.3 (Sahelian crossbred), and 14.0 (European crossbred) animals. The cows of the studied dairy farms were all hand milked. Calves of local zebu cows were allowed to suckle their mother before milking to stimulate milk letdown after milking to feed the calf, as is common practice in the region (Zezza et al., 2016). European crossbred cows do not need this stimulus for milk letdown and were thus fully milked by the producers. As a consequence, the daily milk offtake on the farms ranged from 0.8 to $10.2 \mathrm{~kg}$, with an average of $5.2 \mathrm{~kg}$. On 3 farms, cows were milked once a day throughout the whole study period, and 2 of these farms stopped milking during the late dry season. Across the remaining 4 farms, the milking frequency varied depending on the lactation stage of the cow and season. The feeding of dairy cattle was based on natural pasture and homestead feeding with energy, protein, and roughage feed. The composition and amounts of 
homestead feeds and the feeding management varied considerably between and within farms over the study period (Plagemann et al., 2017). Cattle were housed in simple compounds with trees or roofed areas to protect them against the sun.

During each farm visit, the actual physiological status of female animals (dry, pregnant, lactating), the BW, and the milk offtake and milk composition of individual cows were assessed. All animals were ear tagged or were described phenotypically (color, horned or polled, marks, and other phenotypical characteristics) and assigned to a breed by the owner or farm manager. Their sex and age or birth date were recorded when they were first assessed. For age estimation, the farm managers were asked to indicate the animal's age rounded to the month for animals younger than $1 \mathrm{yr}$ and to the year for older animals. For calves that were born during the 16-mo data collection period, the birthdate was used to calculate the age in months.

A wooden weighing platform connected to an AGRETO scale construction kit (AGRETO Electronics GmbH, Raabs, Austria) was used to weigh all animals that were present at the time of each visit. Highly agitated or aggressive animals and cows in late gestation or directly after calving were excluded from the weighing. Missing BW records were imputed by interpolation technique. The milk that was extracted for selling was quantified over 2 consecutive days in all cows in the herds that were present at the time of the visits. In the case cows were milked twice a day, morning and evening milk was collected; for the remaining cows, the milk offtake was either assessed in the morning or in the evening, depending on the time of milking in the respective farm. The milk was weighed using a bucket and a hanging scale (TARA PS 7600, Burg Wächter, Wetter, Germany; weight range $40 \mathrm{~kg}$ ). A milk sample of one milking per visit was taken and analyzed for fat $(\mathbf{F})$ and protein $(\mathbf{P}$; measuring range $2-7 \%$, accuracy $\pm 0.15 \%$ ) using an ultrasonic milk analyzer (Master Eco, Milkotester Ltd., Belovo, Bulgaria).

The initial database contained 1,380 weight records of 219 female cattle, 412 milk offtake records of 77 cows, and 334 observations for milk fat and protein percentage from 72 cows. Records were checked for logical inconsistencies and biological incompatibilities. Animals with more than 1 missing weight record, and hence more than 1 interpolation between 2 visits, were excluded. Due to a low number of milked cows throughout the study period and irregular milking of cows, the milk data of 2 farms were not further considered. For the remaining 5 farms, all cows with milk offtake records for 2 consecutive days and for at least 2 out of the 10 visits were included for statistical analysis. All milk samples with a milk fat content of $>6.5 \%$ (Felius, $1995)$ were excluded. Hence, the final data set for BW contained 1,323 observations of 214 female cattle (average number of observations $=6.2$ per animal), and for daily milk offtake it contained 373 observations of 72 cows, with a mean number of 5.2 milk offtake records per cow. We used 299 milk samples of 71 cows for the analyses of the milk fat and protein percentage, with an average number of observations of 4.5 per cow (Table 1). The milk fat-to-milk protein ratio $(\% / \%)$ of the 299 milk samples was used as an indicator for the risk of ketosis and acidosis. An F/P value of $>1.5$ means ketosis risk (Heuer et al., 1999), whereas an $\mathrm{F} / \mathrm{P}$ of $<1.0$ indicates a risk of acidosis (Gantner et al., 2016). In the case that a cow had a positive result, she was assigned a value of 1 , otherwise 0 .

\section{Statistical Analyses}

The variables of interest were the average daily milk offtake per cow (DMO; kg), F and P percentages of individual test day records, the risk of ketosis and acidosis $(1=$ yes $/ 0=$ no $)$, and the BW of young (BWy; $1-18$ mo of age) and adult (BWa; >18 mo of age) female cattle. The average DMO per cow was calculated over the 2 test day records of each visit. The prevalence of ketosis or acidosis was calculated as the frequency of cows with an $\mathrm{F} / \mathrm{P}$ ratio of $>1.5$ or $<1.0$ in the total number of cows according to breed group, season, lactation number, and lactation stage. Cows with $>1$ positive result within factor levels were only considered once.

To assess genetic differences in the variables of interest, cows were grouped by their general genetic background into (1) purebreds of the local zebu Peul breed (local zebu), (2) crossbreds between local zebu and Sahelian zebu breeds (Sahelian cross), and (3) crossbreds between local zebu and European/international cattle breeds (European cross). Although the genetic background of the cows in groups 2 and 3 was quite heterogeneous, crossbred cows can be clearly differentiated from local zebu cows and differences between breed groups represent genetic differences. Besides genetic differences, the influence of environmental factors on cow performance was investigated, including the season, the lactation number and lactation stage, and the reproductive status. Three seasons were defined, namely the rainy season (RS) from July 1 until October 15, the early dry season (EDS) from October 16 until February 15, and the late dry season (LDS) from February 16 until June 30. Four levels for the lactation number $(1=$ first, $2=$ second, $3=$ third, $4=$ fourth or greater), and 3 levels for the lactation stage 


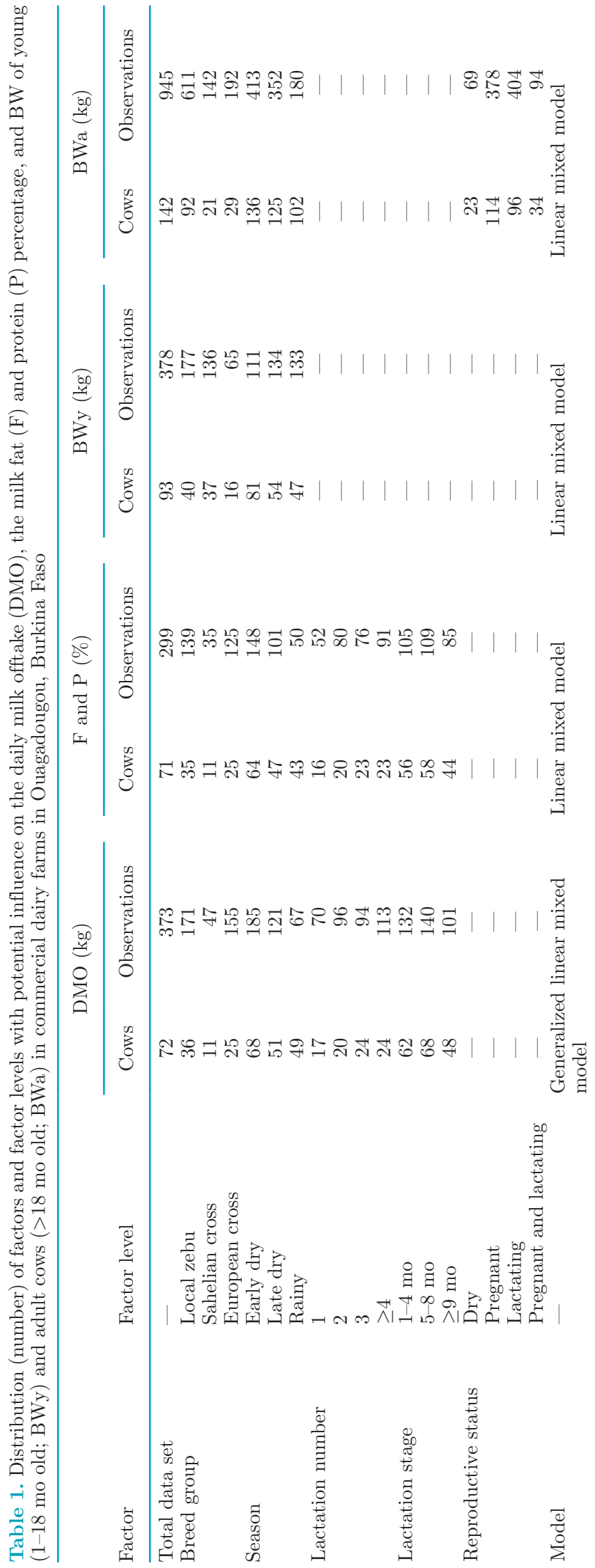

(early lactation $=1-4 \mathrm{mo}$, mid lactation $=5-8 \mathrm{mo}$, late lactation $\geq 9 \mathrm{mo}$ ) were considered. Both BWy and BWa were adjusted for the age of the cow $(\mathrm{BWy}=$ linear and quadratic; $\mathrm{BWa}=$ linear) and BWa for the reproductive status (dry, pregnant, lactating, pregnant and lactating). The milking frequency (once a day, twice a day) was strongly related to the season and lactation stage and the farm to the breed group; therefore, milking frequency and farm were excluded from further statistical analysis. The independence of fixed effects was evaluated by Chi-squared test.

A generalized linear mixed model using penalized quasi-likelihood (glmmpql) was fitted to evaluate the effects on DMO, and linear mixed models (lmer) were fitted to analyze the effects on the $\mathrm{F}$ and $\mathrm{P}$ percentage as well as on BWy and BWa. Animal was considered as random factor in all models. We found no additional farm-level variation to warrant adding "farm" as an additional farm-level random effect to explain all the observed variation. Least squares means for the described factors were compared with the Tukey (HSD) method. To compare the prevalence of ketosis and acidosis between breed groups, seasons, lactation numbers, and lactation stages, Pearson's Chi-squared test or Fisher's exact test was used.

Following the genetic and environmental effect analysis of BWy and BWa, nonlinear growth functions were fit to the data to model the relationship between BW and age adjusted for the breed group, the season, and the reproductive status (pregnant or nonpregnant). A 2 -step approach was used. First, 5 of the most widely used nonlinear models (Brody, Gompertz, van Bertalanffy, logistic, and Richards functions) were fit to the total data to model the relationship between $\mathrm{BW}$ and age without correction for genotypic and environmental factors. The age and BW thereby ranged from $0.6 \mathrm{wk}$ up to $17 \mathrm{yr}$ of age $($ mean $=56 \mathrm{mo}, \mathrm{SD}=40.1 \mathrm{mo})$ and from 8.9 to $641 \mathrm{~kg}$ (mean $=236 \mathrm{~kg}, \mathrm{SD}=135.2 \mathrm{~kg}$ ), respectively. The models were compared based on the residual sum of squares (RSS), the ability to converge and the significance level of the parameter estimates. The Gompertz function gave the best fit for the total data set $(\mathrm{RSS}=10,206,752$; number of iterations to convergence $=6 ; P<0.001$ for all parameter estimates) and was used to develop growth curves adjusted for breed group, season, and pregnancy of cows in the second step. Parameters of interest obtained from the models included the mature weight (A) and the maturing rate $(\mathrm{k})$.

All statistical analyses and figure production were performed in $\mathrm{R}$ version 3.5.0, using additional functions provided in the $\mathrm{R}$ packages lme4 (Bates et al., 2015), lmerTest (Kuznetsova et al., 2017), car (Fox and Weisberg, 2011), MASS (Venables and Ripley, 2002), mult- 
comp (Hothorn et al., 2008), lsmeans (Lenth, 2016), and lattice (Sarkar, 2008). The level of significance was set at $P<0.05$.

\section{RESULTS}

\section{DMO and Milk Fat and Protein Percentage}

Results for DMO and milk composition of cows of different breed groups, lactation numbers, and lactation stages as well as in different seasons are presented in Table 2. The DMO differed according to breed group $(P<0.001)$, season $(P<0.05)$, and lactation stage $(P$ $<0.001)$. It was more than 4 and 3 times higher from European $(8.6 \pm 0.77 \mathrm{~kg})$ and Sahelian crossbreds $(6.2$ $\pm 0.87 \mathrm{~kg})$ than from local zebu cows $(2.0 \pm 0.20 \mathrm{~kg}$; $P<0.001)$. The DMO was highest in RS $(5.8 \pm 0.43$ $\mathrm{kg})$ and lowest in $\operatorname{EDS}(5.3 \pm 0.37 \mathrm{~kg})(P<0.05)$. The DMO gradually decreased from $7.5 \pm 0.52 \mathrm{~kg}$ in early lactation, to $5.7 \pm 0.40 \mathrm{~kg}$ in mid-lactation and 3.6 $\pm 0.28 \mathrm{~kg}$ in late lactation; it was not affected by the lactation number $(P>0.05$; Table 2$)$.

Environmental factors had an effect on the milk composition, but these were different between $\mathrm{F}$ and $\mathrm{P}$. Whereas $\mathrm{F}$ percentage was influenced by the season $(P$ $<0.05)$ and the lactation stage $(P<0.001)$, but not by the lactation number $(P>0.05)$, the latter was the only factor that affected $\mathrm{P}$ percentage $(P<0.05)$. Accordingly, the highest $\mathrm{F}$ percentages were observed in RS ( $P$ $<0.05$ compared with EDS), as well as in mid-lactation $(P<0.05$ compared with LDS $)$ and late lactation $(P<$
0.001 compared with LDS). Cows in their first lactation had the highest $\mathrm{P}$ percentage, with significant differences to cows in their third lactation $(P<0.01)$. The $\mathrm{F}$ and $\mathrm{P}$ percentage of the cow milk that was produced in the studied dairy farms in Ouagadougou were not influenced by the genotype $(P>0.05)$.

\section{Prevalence of Ketosis and Acidosis}

The analysis of the $\mathrm{F} / \mathrm{P}$ values of the 299 milk samples revealed that 57 and 14 of the 71 lactating cows had a value of $>1.5$ and of $<1.0$ at least once during the 16-mo study period, representing an overall prevalence rate of $80.3 \%$ for ketosis and $19.7 \%$ for acidosis, respectively. The prevalence rate of both metabolic diseases was influenced by the lactation stage, but in the opposite direction. Whereas the prevalence rate of ketosis was higher in cows in late lactation than in early- and mid-lactation cows $(P<0.05)$, the prevalence rate of acidosis was highest in early-lactation cows $(P<0.01)$. The genotype, season and lactation number had no effect on the prevalence rates $(P>0.05$; Table 3$)$.

\section{BW, Mature Weight, and Maturing Rate of Cows}

The least squares means for the genetic and environmental effects on BWy and BWa on commercial dairy farms in Ouagadougou are presented in Table 4. The BWy was affected positively $(P<0.001)$ by the linear and negatively $(P<0.001)$ by the quadratic effect of the age, as well as the season $(P<0.001)$. It was

Table 2. Least squares means \pm SE for breed group and environmental effects on the daily milk offtake and milk composition in commercial dairy farms in Ouagadougou, Burkina Faso ${ }^{1}$

\begin{tabular}{lccc}
\hline Effect & $\begin{array}{c}\text { Daily milk } \\
\text { offtake }(\mathrm{kg})\end{array}$ & $\begin{array}{c}\text { Milk fat } \\
(\%)\end{array}$ & $\begin{array}{c}\text { Milk } \\
\text { protein }(\%)\end{array}$ \\
\hline Breed group & $* * *$ & $\mathrm{NS}$ & $\mathrm{NS}$ \\
Local zebu & $2.0 \pm 0.20^{\mathrm{a}}$ & $4.65 \pm 0.103$ & $3.21 \pm 0.021$ \\
Sahelian crossbreed & $6.2 \pm 0.87^{\mathrm{b}}$ & $4.81 \pm 0.198$ & $3.18 \pm 0.039$ \\
European crossbred & $\begin{array}{c}* \\
\text { Season }\end{array}$ & $4.62 \pm 0.119$ & $3.16 \pm 0.024$ \\
Early dry & $5.3 \pm 0.37^{\mathrm{a}}$ & $4.56 \pm 0.097^{\mathrm{a}}$ & $\mathrm{NS}$ \\
Late dry & $5.7 \pm 0.40^{\mathrm{ab}}$ & $4.60 \pm 0.109^{\mathrm{ab}}$ & $3.18 \pm 0.019$ \\
Rainy & $5.8 \pm 0.43^{\mathrm{b}}$ & $4.92 \pm 0.138^{\mathrm{b}}$ & $3.18 \pm 0.021$ \\
Lactation number & $\mathrm{NS}$ & $\mathrm{NS}$ & $*$ \\
1 & $5.3 \pm 0.62$ & $4.93 \pm 0.157$ & $3.26 \pm 0.031^{\mathrm{b}}$ \\
2 & $5.7 \pm 0.52$ & $4.62 \pm 0.144$ & $3.18 \pm 0.028^{\mathrm{ab}}$ \\
3 & $5.1 \pm 0.43$ & $4.57 \pm 0.139$ & $3.13 \pm 0.027^{\mathrm{a}}$ \\
$\geq 4$ & $6.2 \pm 0.58$ & $4.65 \pm 0.136$ & $3.16 \pm 0.027^{\mathrm{ab}}$ \\
Lactation stage & $* * *$ & $* * *$ & $\mathrm{NS}$ \\
Early lactation & $7.5 \pm 0.52^{\mathrm{c}}$ & $4.40 \pm 0.105^{\mathrm{a}}$ & $3.16 \pm 0.020$ \\
Mid lactation & $5.7 \pm 0.40^{\mathrm{b}}$ & $4.70 \pm 0.110^{\mathrm{b}}$ & $3.18 \pm 0.021$ \\
Late lactation & $3.6 \pm 0.28^{\mathrm{a}}$ & $4.97 \pm 0.122^{\mathrm{b}}$ & $3.20 \pm 0.023$ \\
\hline
\end{tabular}

${ }^{a-c}$ Values with different superscripts within columns for each factor differ significantly at $P<0.05$.

${ }^{1}$ Results of the generalized linear mixed model (daily milk offtake), linear mixed model (milk fat, milk protein) and pairwise comparison of LSM.

${ }^{*} P<0.05,{ }^{* * *} P<0.001, \mathrm{NS}=P>0.05$. 
Table 3. Prevalence of ketosis (percentage of cows with an $\mathrm{F} / \mathrm{P}^{1}$ quotient of $>1.5$ ) and acidosis (percentage of cows with an $\mathrm{F} / \mathrm{P}$ quotient of $<1.0$ ) among lactating cows in commercial dairy farms in Ouagadougou, Burkina Faso

\begin{tabular}{lccc}
\hline Effect & $\begin{array}{c}\text { Cows } \\
(\mathrm{n})\end{array}$ & $\begin{array}{c}\text { Ketosis } \\
\text { \% of cows })\end{array}$ & $\begin{array}{c}\text { Acidosis } \\
\text { (\% of cows) }\end{array}$ \\
\hline Total & 71 & 80.3 & 19.7 \\
Breed group & & $\mathrm{NS}$ & $\mathrm{NS}$ \\
$\quad$ Local zebu & 35 & 82.8 & 24.0 \\
Sahelian cross & 11 & 72.7 & 0.0 \\
European cross & 25 & 80.0 & 22.9 \\
Season & & $\mathrm{NS}$ & $\mathrm{NS}$ \\
Early dry season & 64 & 54.7 & 12.5 \\
Late dry season & 47 & 61.7 & 10.6 \\
Rainy season & 43 & $\mathrm{NS}$ & 4.7 \\
Lactation number & & 81.3 & $\mathrm{NS}$ \\
1 & 16 & 65.0 & 6.3 \\
2 & 20 & 60.9 & 25.0 \\
3 & 23 & 87.0 & 26.1 \\
$\geq 4$ & 23 & $*$ & 13.4 \\
Lactation stage & & 48.2 & 21.4 \\
Early lactation & 56 & 51.7 & 5.2 \\
Mid lactation & 58 & 72.7 & 2.3 \\
Late lactation & 44 & & \\
\hline
\end{tabular}

${ }^{1} \mathrm{~F} / \mathrm{P}=$ milk fat to milk protein ratio.

${ }^{*} * P<0.01, * P<0.05, \mathrm{NS}=P>0.05$.

lower in RS as compared with EDS and LDS (both $P<$ 0.001). The genotype had no effect $(P>0.05)$ on BWy.

On the contrary, BWa was affected by the genotype $(P<0.001)$, with highest BW observed for European crossbred cows $(P<0.05$ compared with Sahelian crossbred and $P<0.001$ compared with local zebu cows) and lowest BW for local zebu cows $(P<0.001$ compared

Table 4. Least squares means \pm SE for breed and environmental factors $^{1}$ on the BW of young (1-18 mo of age) and adult cows $(>18$ mo of age)

\begin{tabular}{lcc}
\hline & \multicolumn{2}{c}{ BW $(\mathrm{kg})$} \\
\cline { 2 - 3 } Effect or covariate & Young cows & Adult cows \\
\hline Age (months) & $* * *$ & $* * *$ \\
Age $^{2}$ (months) & $* * *$ & $\mathrm{NA}^{2}$ \\
Breed group & $\mathrm{NS}$ & $* * *$ \\
Local zebu & $89.1 \pm 4.42$ & $240.6 \pm 6.99^{\mathrm{a}}$ \\
Sahelian cross & $90.9 \pm 4.48$ & $396.5 \pm 17.31^{\mathrm{b}}$ \\
European cross & $89.6 \pm 5.03$ & $450.0 \pm 12.12^{\mathrm{c}}$ \\
Season & $* * *$ & $* * *$ \\
Early dry & $96.2 \pm 4.16^{\mathrm{b}}$ & $374.0 \pm 7.51^{\mathrm{c}}$ \\
Late dry & $93.4 \pm 4.43^{\mathrm{b}}$ & $365.9 \pm 7.58^{\mathrm{b}}$ \\
Rainy & $80.0 \pm 4.29^{\mathrm{a}}$ & $347.3 \pm 7.63^{\mathrm{a}}$ \\
Reproductive status & $\mathrm{NA}$ & $* * *$ \\
Dry and empty & - & $357.4 \pm 8.76^{\mathrm{ab}}$ \\
Pregnant & - & $372.1 \pm 7.51^{\mathrm{c}}$ \\
Lactating & - & $354.1 \pm 7.42^{\mathrm{a}}$ \\
Lactating and pregnant & - & $365.9 \pm 7.79^{\mathrm{bc}}$ \\
\hline
\end{tabular}

${ }^{\mathrm{a}-\mathrm{c}}$ Values with different superscripts within columns for each factor differ significantly at $P<0.05$.

${ }^{1}$ Results of the linear mixed model and pairwise comparisons of LSM.

${ }^{2} \mathrm{NA}=$ not applicable.

$* * * P<0.001, \mathrm{NS}=P>0.05$. with European and Sahelian crossbred cows). Similar to BWy, BWa was also influenced positively by the linear effect of the age and the season (both $P<0.001$ ). Again, lowest BW were observed in RS and highest BW in $\operatorname{EDS}(P<0.001$ for all pairwise comparisons). As could be expected, pregnant (nonlactating) cows had higher BW than dry empty $(P<0.01)$ and lactating (nonpregnant) cows $(P<0.001)$. In addition, lactating and pregnant cows were heavier than lactating (nonpregnant) cows $(P<0.001)$, whereas their $\mathrm{BW}$ was similar to that of dry empty cows $(P>0.05)$. The BW of dry empty and lactating (nonpregnant) cows were similar $(P>0.05)$.

The asymptotic regression lines of the Gompertz model illustrate the effects of genotype, season, and pregnancy on the weight development of the cows in commercial dairy farms in Ouagadougou (Figure 1). Crossbred cows were able to more rapidly increase their weight with age, whereas the growth rate of the local zebu cows was relatively low. Accordingly, crossbred cows exhibited heavier mature weights and Sahelian crossbred cows, in particular, attained maturity faster than the average, as indicated by the relative $\mathrm{k}$ value (Table 5). In contrast, the mature weight and relative growth rate to maturity of the local zebu cows were approximately 18 and 19\% less than the total average, respectively. The environmental effect on the slope of the growth curve showed that the mature weight of cows was lower in RS; also the maturity rate was affected, being lowest in LDS and highest in EDS. The mature weight and maturing rate were also affected by 
the pregnancy of cows. However, the effects of the season and the pregnancy on the BW development of cows were less pronounced than the breed effect.
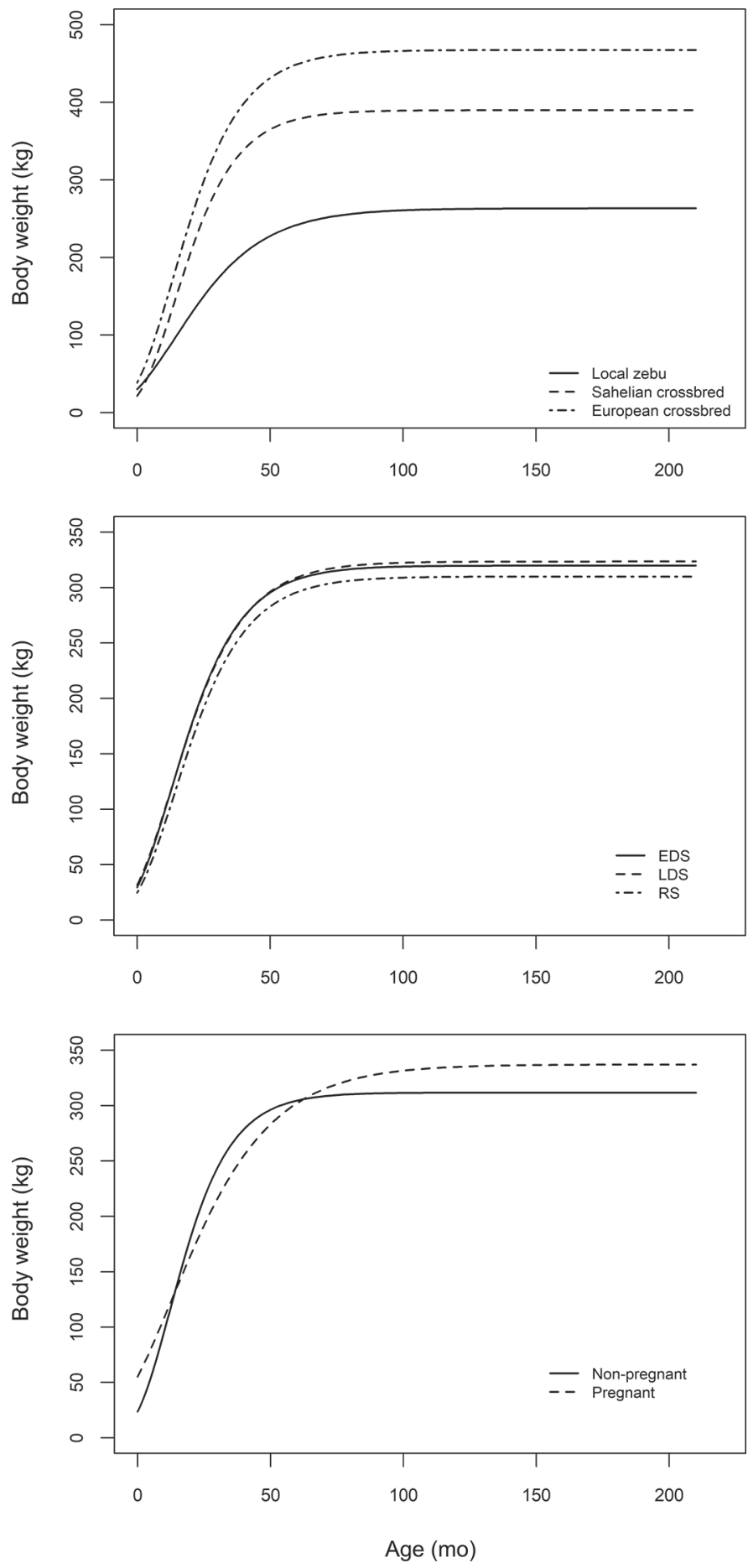

Figure 1. Effect of breed group, season, and pregnancy on BW development of cows in commercial dairy farms in Ouagadougou, Burkina Faso, estimated by the Gompertz function based on averaged weight values within factor levels. EDS = early dry season; LDS = late dry season; RS = rainy season.

\section{DISCUSSION}

\section{DMO}

In dairy cattle herds in peri-urban areas of Ouagadougou, the DMO from crossbred cows was 3.1 (Sahelian cross) to 4.3 fold (European cross) higher than from purebred local zebu cows. In our study, partial milking and calf suckling were practiced in zebu cows, whereas crossbred cows were fully milked by the producer, which explains the lower DMO from zebu cows. Still, the differences in DMO could be also attributed to a higher genetic potential of European crossbred cows, as has been also shown in a comparative study of local Horro zebu and Jersey $\times$ Horro crossbred cows in Ethiopia (Hundie et al., 2014). The least squares means of DMO from crossbred cows in our study (8.6 and $6.2 \mathrm{~kg}$ ) were higher than the 2 to $5 \mathrm{~L}$ that have been reported by cattle keepers in Ouagadougou in a previous study (Millogo et al., 2008). Besides potential genetic differences, various environmental factors influenced DMO in our study. Similar to Hundie et al. (2014), we observed the highest DMO in RS, whereas Epaphras et al. (2004) did not report any seasonal differences in the milk offtake from Ayrshire crossbred cows in Tanzania. The seasonal variations in DMO in our study can be explained by a seasonal breeding activity of cows in SSA and the seasonal fluctuations in the availability and quality of feed resources (Zezza et al., 2016). The late dry season in SSA is characterized by extreme heat stress conditions as well as feed and water scarcity (Amole and Ayantunde, 2016), making intensive milk production difficult for most of the year (giz, 2018). Similar to Zezza et al. (2016), we observed a peak of calvings in the last months of LDS and the first month of RS (45\%; Appendix Figure A1), further explaining the higher milk offtake during RS. In this season, a large share of cows is in early lactation and we calculated least squares means of $7.5 \mathrm{~kg}$. In the following lactation stages, DMO gradually decreased to $5.7 \mathrm{~kg}$ in mid lactation and $3.6 \mathrm{~kg}$ in late lactation. The same effect of the lactation stage on the milk offtake was also reported for cows in Ethiopia (Duguma et al., 2012). However, in contrast to Epaphras et al. (2004), who demonstrated a positive relationship between daily milk production and lactation number until the third lactation, DMO did not significantly increase with higher lactation numbers in our study.

\section{Milk Composition and Prevalence of Ketosis and Acidosis}

The $\mathrm{F}$ percentage of the cow milk produced on the peri-urban dairy farms of Ouagadougou was similar 
Table 5. Predicted mature weight and maturing rate of cows in commercial dairy farms in Ouagadougou, Burkina Faso ${ }^{1}$

\begin{tabular}{lccc}
\hline Effect & $\begin{array}{c}\text { Observations } \\
(\mathrm{n})\end{array}$ & $\begin{array}{c}\text { Mature weight } \\
(A ; \mathrm{kg})\end{array}$ & $\begin{array}{c}\text { Maturing rate } \\
(k ; \%)\end{array}$ \\
\hline Total data set & 1,323 & 319 & 100.0 \\
Breed group & 788 & 263 & 80.7 \\
$\quad$ Local zebu & 278 & 390 & 113.0 \\
Sahelian cross & 257 & 468 & 102.6 \\
European cross & 597 & 319.8 & 101.8 \\
Season & 480 & 323.5 & 97.8 \\
Early dry & 246 & 310.0 & 99.4 \\
Late dry & 851 & 311.7 & 117.3 \\
Rainy & 472 & 337.1 & 70.0 \\
Pregnancy & & & \\
Nonpregnant & \multicolumn{2}{c}{ Pregnant } &
\end{tabular}

to values reported in previous studies in Burkina Faso (Millogo et al., 2008), Mali (Bonfoh et al., 2005), and Nigeria (Tona et al., 2017), whereas the P percentage in our study was lower than for cows in Nigeria $(5.3 \%$; Tona et al., 2017), Benin (Houaga et al., 2018) ,and Mali (3.7\%; Bonfoh et al., 2005). Various factors have been documented to influence the milk composition, such as the breed, lactation number and stage, as well as seasonal and managerial factors. Unlike Nóbrega and Langoni (2011) and Houaga et al. (2018), we could not observe a genetic effect on the variation of the milk fat and protein content; however, various environmental factors influenced the $\mathrm{F}$ and $\mathrm{P}$ percentage. The season and the lactation stage affected the $\mathrm{F}$ percentage, whereas the highest $\mathrm{P}$ percentages were determined for cows in their first lactation. Similar to a study of Holstein and Jersey cows in Brazil, the F percentage of the milk samples in our study were highest in RS (Nóbrega and Langoni, 2011); however, in contrast to the latter study, the $\mathrm{P}$ percentage in our study was unaffected by the season. The seasonal variations in $\mathrm{F}$ percentage could be explained by dietary differences between seasons. Supplementary feeding of dairy cows in LDS is mostly composed of cereal straws and hays with high cellulose (NDF) content [E. Schlecht, J. Plagemann (University of Kassel and University of Goettingen), S. E. Mpouam, H. O. Sanon (Institut de l'Environnement et de Recherches Agricoles, Ouagadougou, Burkina Faso), M. Sangaré (Centre International de RechercheDéveloppement sur l'Elevage en zone Subhumide, BobDioulasso, Burkina Faso), and R. Roessler, unpublished data]. A higher NDF content of the feed leads to a linear increase in the milk fat content, due to a higher acetic acid production in the rumen (Arelovich et al., 2008). The low and unbalanced energy and protein sup- ply [E. Schlecht, J. Plagemann (University of Kassel and University of Goettingen), S. E. Mpouam, H. O. Sanon (Institut de l'Environnement et de Recherches Agricoles, Ouagadougou, Burkina Faso), M. Sangaré (Centre International de Recherche-Développement sur l'Elevage en zone Subhumide, Bob-Dioulasso, Burkina Faso), and R. Roessler, unpublished data] potentially led to the mobilization of body fat, as also shown for local zebu cows in Mali (Bonfoh et al., 2005), which could further explain the relatively high $\mathrm{F}$ percentage, and hence the wide $\mathrm{F} / \mathrm{P}$ ratio.

A general paucity of studies exist assessing prevalence rates of ketosis in dairy cows in developing countries. To the best of our knowledge, only one study reported prevalence rates of ketosis in local cattle breeds and their crossbreds with Holstein or Jersey in India (Biswal et al., 2016). The prevalence rate in their study was much lower $(36.7 \%)$ than the prevalence rate in our study; however, those authors used ketone bodies in urine, milk, and blood as indicators, making a comparison with our results difficult. Comparing our results with studies that have used the $\mathrm{F} / \mathrm{P}$ ratio for cows in Italy (33\%; Toni et al., 2011) and Slovakia (12\%; Vlček et al., 2016), the prevalence rate obtained in our study is still extremely high. Previous studies revealed environmental differences in the prevalence rate of ketosis. For example, Biswal et al. (2016) and Gantner et al. (2016) concluded that the prevalence rate was influenced by the lactation number and stage. In our study, the lactation number had no influence on the prevalence of ketosis. However, the risk for ketosis increased in the course of the lactation, whereas previous studies (Biswal et al., 2016; Gantner et al., 2016) observed an opposite trend with a higher prevalence in early lactation. Furthermore, Biswal et al. (2016) 
observed seasonal differences in the prevalence rate of ketosis, which contradicts our results that indicated no seasonal influence on the risk of ketosis. Similar to the results of the study of Biswal et al. (2016), no genetic variation in the prevalence of ketosis in our study was revealed. Acidosis is commonly observed in dairy cows that are overfed grain diets high in starch and low in fiber (Oba and Wertz-Lutz, 2011). Although, feeding of high amounts of grains is uncommon in peri-urban dairy farms in Ouagadougou [E. Schlecht, J. Plagemann (University of Kassel and University of Goettingen), S. E. Mpouam, H. O. Sanon (Institut de l'Environnement et de Recherches Agricoles, Ouagadougou, Burkina Faso), M. Sangaré (Centre International de RechercheDéveloppement sur l'Elevage en zone Subhumide, BobDioulasso, Burkina Faso), and R. Roessler, unpublished data], the prevalence of acidosis in our study, as indicated by a $\mathrm{F} / \mathrm{P}$ quotient of $<1.0$, was unexpectedly high $(19.7 \%)$ and comparable to values obtained for Holstein cows in Croatia (Gantner et al., 2016). We noted a declining trend in the course of the lactation, which contradicts other studies (Gantner et al., 2016; Vlček et al., 2016) where prevalence rates of acidosis have been increasing; however, those studies only assessed the prevalence rate up to the fifth lactation month. In summary, systematic studies are needed that compare different methods using a larger number of dairy cows to prove the suitability of the $\mathrm{F} / \mathrm{P}$ ratio in local and crossbred cattle genotypes in tropical dairy production systems, and to define genotype-specific threshold values of the $\mathrm{F} / \mathrm{P}$ quotient to determine the risk of ketosis and also acidosis in these systems.

\section{BW Development}

The BW of adult ( $>18$ mo of age) local zebu cows in our study was similar to the cow weight $(230-240 \mathrm{~kg})$ reported in Felius (1995), whereas the BW of European crossbred cows was considerably higher than the BW of European crossbred cows in Senegal (383-392 kg; Tebug et al., 2018). However, one should note that the genetic background of cows in Senegal was different to that in our study, and that these cows had at least $3 \mathrm{yr}$ of age with no information on the physiological status and were reared in low-input production systems (Tebug et al., 2018). Sahelien zebu cows (Azawak, Bororo and Gudali) are heavier than local zebu cows (Felius, 1995), and therefore the Sahelian zebu crosses in our study had higher cow weights than purebred local zebu cows. As expected, the reproductive status influenced the BW of cows. The highest BW were recorded in pregnant cows after drying off and the lowest BW in lactating cows before the next gestation. The increasing energy demand for milk production after parturition often exceeds the cows' capacity to ingest enough feed to supply their energy requirements; therefore, cows usually mobilize body reserves and lose weight in early lactation ( ̌̌ehák et al., 2012). Until the end of the lactation, cows increased their BW due to pregnancy. The seasonal variation in BW of both young and adult cows in our study could be explained by seasonally variable quality, quantity, and price of feedstuffs in Burkina Faso. Particularly in LDS, the quantity and quality of livestock feed is insufficient (Amole and Ayantunde, 2016). Furthermore, extreme heat stress conditions could have further limited the feed intake in cows. Together, all of these factors could explain the lower BW of cows in our study in this season as compared with EDS. However, BW losses were not limited to EDS, and the lowest BW in young and adult cows in our study were recorded in RS. Likewise, Fernández-Rivera et al. (2005) demonstrated that cattle in the Sahel can lose up to $300 \mathrm{~g} / \mathrm{d}$ of BW in the late dry and the transition period between the dry and rainy season. According to those authors, this is due to the onset of rains that leads to spoilage of the remaining roughage and a direct effect of the rains on the animals. Particularly in the RS, natural grasslands contribute considerably to the total feed intake of dairy cows, whereas supplementation with protein and energy rich feeds is restricted [E. Schlecht, J. Plagemann (University of Kassel and University of Goettingen), S. E. Mpouam, H. O. Sanon (Institut de l'Environnement et de Recherches Agricoles, Ouagadougou, Burkina Faso), M. Sangaré (Centre International de Recherche-Développement sur l'Elevage en zone Subhumide, Bob-Dioulasso, Burkina Faso), and R. Roessler, unpublished data]. However, the pastures in the periphery of Ouagadougou are dominated by annual grass species with a low pastoral value [C. Sarambé (Centre International de RechercheDéveloppement sur l'Elevage en zone Subhumide, BobDioulasso, Burkina Faso), M. L. Kaboré (Université Polytechnique de Bobo-Dioulassom Bobo-Dioulasso, Burkina Faso), N. Zampaligré (Centre International de Recherche-Développement sur l'Elevage en zone Subhumide), R. Roessler, and M. Sangaré (Centre International de Recherche-Développement sur l'Elevage en zone Subhumide), unpublished data], which may further explain the BW losses in RS.

The genetic differences in the BW of cows in our study are also reflected in the shape of the growth curves. Crossbred cows grew faster and had higher BW at maturity than local zebu cows. Similarly, Ouedraogo (2013) demonstrated a higher growth rate in Azawak crossbred as compared with local zebu cattle, although that study was limited to calves from 0 to 6 mo of age. The lower maturity rate in European than in Sahelian crossbreds might be due to a lower adapta- 
tion of European crossbreds to the prevailing climatic conditions. In contrast, the shape of the growth curve and the estimates of mature weight and maturity rate are similar for cows in different seasons. In addition, the adjustment for pregnancy shows that the effect of gestation on the normal growth of cows is rather small.

\section{CONCLUSIONS}

The daily milk offtake from Sahelian and European crossbred genotypes was higher than from local zebu cows. Likewise, crossbred cows ( $>18$ mo of age) had comparatively higher BW and mature weights and grew faster than local zebu cows. However, production performances were also influenced by seasonal and other environmental factors that have to be accounted for when planning breeding and management programs for dairy cattle in Burkina Faso. In particular, the feeding management in the late dry and rainy season needs to be improved to reduce BW losses and the risk of metabolic disorders in dairy cows in commercial farms in Burkina Faso. Further studies are needed that systematically evaluate crossbreeding effects and genotype by environment interactions on broader scale to develop sustainable breeding programs for dairy cattle in the region.

\section{ACKNOWLEDGMENTS}

This work was carried out as part of the UrbanFood ${ }^{\text {Plus }}$ Project (http://www.urbanfoodplus.org/index .php?id=5), jointly funded by the German Federal Ministry of Education and Research (BMBF, Bonn and Berlin, Germany) and the German Federal Ministry for Economic Cooperation and Development (BMZ, Bonn and Berlin, Germany) under the initiative GlobE Research for the Global Food Supply, grant number 031A242-A. The sponsors had no role in the design of the study; in the collection, analyses, or interpretation of data; in the writing of the manuscript, and in the decision to publish the results. Special thanks go to Bokoum Hassane (Ouagadougou, Burkina Faso) for his continuous support in facilitating the collection of data, to Julian Plagemann (University of Kassel and University of Goettingen) for creating the UrbanFood ${ }^{\text {Plus }}$ database, and to Mamadou Sangaré (Centre International de Recherche-Développement sur l'Elevage en zone Subhumide, Bobo-Dioulasso, Burkina Faso) and Hadja Oumou Sanon (Institut de l'Environnement et de Recherches Agricoles, Ouagadougou, Burkina Faso) for stimulating collaboration. Last but not least, we thank all livestock keepers for their willingness to participate in this study and to accept our visits over the 16-month data collection period.

\section{REFERENCES}

Amadou, H., L. H. Dossa, D. J.-P. Lompo, A. Abdulkadir, and E. Schlecht. 2012. A comparison between urban livestock production strategies in Burkina Faso, Mali and Nigeria in West Africa. Trop. Anim. Health Prod. 44:1631-1642. https://doi.org/10.1007/ s11250-012-0118-0.

Amole, T. A., and A. A. Ayantunde. 2016. Improving livestock productivity: Assessment of feed resources and livestock management practices in Sudan-Savanna zones of West Africa. Afr. J. Agric. Res. 11:422-440. https://doi.org/10.5897/AJAR2015.10460.

Arelovich, H. M., C. S. Abney, J. A. Vizcarra, and M. L. Galyean. 2008. Effects of dietary neutral detergent fiber on intakes of dry matter and net energy by dairy and beef cattle: Analysis of published data. Prof. Anim. Sci. 24:375-383. https://doi.org/10 .15232/S1080-7446(15)30882-2.

Awumbila, M. 2017. Drivers of migration and urbanization in Africa: Key trends and issues. Background paper prepared for the United Nations expert group meeting on sustainable cities, human mobility and international migration. September 7-8, 2017. Population division, Department of Economic and Social Affairs, United Nations Secretariat, New York, NY.

Bates, D., M. Maechler, B. Bolker, and S. Walker. 2015. Fitting linear mixed-effects models using lme4. J. Stat. Softw. 67:1-48. https:// doi.org/10.18637/jss.v067.i01.

Biswal, S., D. C. Nayak, and K. K. Sardar. 2016. Prevalence of ketosis in dairy cows in milk shed areas of Odisha state, India. Vet. World 9:1242-1247. https://doi.org/10.14202/vetworld.2016.1242-1247.

Bonfoh, B., J. Zinsstag, Z. Farah, C. F. Simbé, I. O. Alfaroukh, R. Aebi, R. Badertscher, M. Collomb, J. Meyer, and B. Rehberger. 2005. Raw milk composition of Malian zebu cows (Bos indicus) raised under traditional system. J. Food Comp. Anal. 18:29-38. https://doi.org/10.1016/j.jfca.2003.12.014.

Duguma, B., Y. Kechero, and G. P. J. Janssens. 2012. Productive and reproductive performance of zebu $\mathrm{x}$ Holstein-Friesian crossbred dairy cows in Jimma town, Oromia, Ethiopia. Glob. Vet. 8:67-72.

Epaphras, A., E. D. Karimuribo, and S. N. Msellem. 2004. Effect of season and parity on lactation of crossbred Ayrshire cows reared under coastal tropical climate in Tanzania. Livest. Res. Rural Dev. 16:42. http://www.lrrd.org/lrrd16/6/epap16042.htm.

FAOSTAT. 2016. FAOSTAT Database. Food and Agriculture Organization of the United Nations (FAO). Accessed Jul. 2, 2018. http:/ /www.fao.org/faostat/en/?\#data/QL. ().

Felius, M. 1995. Cattle Breeds. An Encyclopedia. Misset, Doetingchem, the Netherlands.

Fernández-Rivera, S., P. Hiernaux, T. O. Williams, M. D. Turner, E. Schlecht, A. Salla, A. A. Ayandunde, and M. Sangaré. 2005. Nutritional constraints to grazing ruminants in the millet-cowpealivestock farming system of the Sahel. Pages 157-182 in Coping with Feed Scarcity in Smallholder Livestock Systems in Developing Countries. A. A. Ayantunde, S. Fernández-Rivera, and G. McCrabb, ed. International Livestock Research Institute, Nairobi, Kenya.

Fox, J., and S. Weisberg. 2011. An $\{\mathrm{R}\}$ companion to applied regression, second edition. Sage Publications, Thousand Oaks, CA.

Gantner, V., T. Bobić, and K. Potočnik. 2016. Prevalence of metabolic disorders and effect on subsequent daily milk quantity and quality in Holstein cows. Arch. Anim. Breed. 59:381-386. https://doi.org/ 10.5194/aab-59-381-2016.

giz (Gesellschaft für Internationale Zusammenarbeit). 2018. The Dairy Sector in Burkina Faso. The Capacity of the Sector and Impact of European Milk Powder Exports. giz, Bonn and Eschborn, Germany.

Gnanda, B. I., D. Bado, S. Reusse, and L. Parel. 2016. Caractéristiques et typologie des exploitations laitières bovines de la zone périurbaine de Ouagadougou, au Burkina Faso. Renc. Rech. Ruminants 23:165-168. http://www.journees3r.fr/IMG/pdf/Texte_2 _Elev_urb_peri_I-Gnanda.pdf.

Goodison, P. 2015. EU dairy sector policies and their impact on countries in sub-Saharan Africa. Initiative for Trade and Development (Initiativet for handel og udvikling), Frederiksberg, Denmark. 
Accessed Jun. 25, 2018. https://www.ihu.dk/media/cms_page _media/40/EU_Dairy_Sector_Policies_and_their_impact_on _Countries_in_Sub-Saharan_Africa.pdf/.

Heuer, C., Y. H. Schukken, and P. Dobbelaar. 1999. Postpartum body condition score and results from the first test day milk as predictors of disease, fertility, yield, and culling in commercial dairy herds. J. Dairy Sci. 82:295-304.

Hothorn, T., F. Bretz, and P. Westfall. 2008. Simultaneous inference in general parametric models. Biom. J. 50:346-363. https://doi.org/ 10.1002/bimj.200810425.

Houaga, I., A. W. T. Muigai, F. M. Ng'ang'a, E. M. Ibeagha-Awemu, M. Kyallo, I. A. K. Youssao, and F. Stomeo. 2018. Milk fatty acid variability and association with polymorphisms in $S C D 1$ and DGAT1 genes in White Fulani and Borgou cattle breeds. Mol. Biol. Rep. 45:1849-1862. https://doi.org/10.1007/s11033-018-4331 -4 .

Hundie, D., F. Beyene, and G. Duguma. 2014. Dairy productive potential, challenges and production opportunities of Horro and their F1 Jersey crossbred cows: A case of Guduru Livestock Production and Research Center and its surroundings, West Oromia, Ethiopia. Sci. Technol. Arts Res. J. 3:79-84. https://doi.org/10.4314/star .v3i4.11.

Kuznetsova, A., P. B. Brockhoff, and R. H. B. Christensen. 2017. lmerTest Package: Tests in linear mixed effects models. J. Stat. Softw. 82:1-26.

Lenth, R. V. 2016. Least-squares means: The R package lsmeans. J. Stat. Softw. 69:1-33. https://doi.org/10.18637/jss.v069.i01.

Millogo, V., G. A. Ouédraogo, S. Agenäs, and K. Svennersten-Sjaunja. 2008. Survey on dairy cattle milk production and milk quality problems in peri-urban areas in Burkina Faso. Afr. J. Agric. Res. $3: 215-224$

Nóbrega, D. B., and H. Langoni. 2011. Breed and season influence on milk quality parameters and in mastitis occurrence. Pesqui. Vet. Bras. 31:1045-1052.

Oba, M., and A. E. Wertz-Lutz. 2011. Ruminant nutrition symposium: Acidosis: New insights into the persistent problem. J. Anim. Sci. 89:1090-1091. https://doi.org/10.2527/jas.2010-3727.

Ouedraogo, A. 2013. Etude des performances laitières des vaches zébus et de la croissance pondérale des veaux des noyaux de Ouagadougou et Komsilga. Mémoire de fin d'études en vue de l'obtention du diplôme d'ingénieur de conception en vulgarisation agricole. Master's thesis equivalent. Polytechnical University of Bobo-Dioulasso, Bobo-Dioulasso, Burkina Faso.

Peel, M. C., B. L. Finlayson, and T. A. Mcmahon. 2007. Updated world map of the Köppen-Geiger climate classification. Hydrol. Earth Syst. Sci. Discuss. 11:1633-1644.

Plagemann, J., S. E. Mpouam, R. Roessler, and E. Schlecht. 2017. Feeding dairy cows, beef cattle and pigs in peri-/urban agriculture in Ouagadougou, Burkina Faso. Page 367 in Future Agriculture: Socio-Ecological Transitions and Bio-Cultural Shifts. E. Tielkes, ed. Cuvillier, Göttingen, Germany.

Řehák, D., J. Volek, L. Bartoň, Z. Vodková, M. Kubešová, and R. Rajmon. 2012. Relationship among milk yield, body weight, and re- production in Holstein and Czeck Fleckvieh cows. Czech J. Anim. Sci. $57: 274-282$.

Roessler, R., S. E. Mpouam, T. Muchemwa, and E. Schlecht. 2016. Emerging development pathways of urban livestock production in rapidly growing West African cities. Sustainability 8:1199. https:/ /doi.org/10.3390/su8111199.

Saghir, J., and J. Santoro. 2018. Urbanization in Sub-Saharan Africa. Meeting challenges by bridging stakeholders. Report. Project on Prosperity and Development. Center for Strategic and International Studies (CSIS), Washington, DC.

Saleh, M. K., T. K. Atala, D. F. Omokore, B. Ahmed, F. S. Ali, and G. Y. Kajang. 2016. Performance of improved dairy cattle technologies among farmers in Northern Nigeria. J. Agric. Ext. 20:1-12. https://doi.org/10.4314/jae.v20i1.1.

Sarkar, D. 2008. Lattice: Multivariate Data Visualization with R. Springer, New York, NY.

Staal, S. J. 2001. The competitiveness of smallholder dairy production: Evidence from sub-Saharan Africa, Asia and Latin America. Pages 250-264 in Smallholder Dairy Production and Marketing-Opportunities and Constraints. D. Rangnekar and W. Thorpe, ed. National Dairy Development Board, Gujarat, India; Australian Centre for International Agricultural Research, Canberra, Australia; and International Livestock Research Institute, Nairobi, Kenya

Tebug, S. F., A. Missohou, S. S. Sabi, J. Juga, E. J. Poole, M. Tapio, and K. Marshall. 2018. Using body measurements to estimate live weight of dairy cattle in low-input systems in Senegal. J. Appl Anim. Res. 46:87-93. https://doi.org/10.1080/09712119.2016 .1262265

Tona, G. O., D. O. Ogunbosoye, D. D. Babalola, and R. T. Oladimeji. 2017. Milk yield (offtake) and composition of White Fulani cows under free range grazing without and with concentrate supplementation. IOSR J. Agric. Vet. Sci. 10:22-27. https://doi.org/10.9790/ 2380-1008022227.

Toni, F., L. Vincenti, L. Grigoletto, A. Ricci, and Y. H. Schukken 2011. Early lactation ratio of fat and protein percentage in milk is associated with health, milk production, and survival. J. Dairy Sci. 94:1772-1783. https://doi.org/10.3168/jds.2010-3389.

United Nations. 2016. The world statistics pocketbook, 2016 edition (series V, No. 40). United Nations, New York, NY. Accessed Jun. 12, 2018. https://unstats.un.org/unsd/publications/pocketbook/ files/world-stats-pocketbook-2016.pdf.

Venables, W. N., and B. D. Ripley. 2002. Modern Applied Statistics with S, 4th ed. Springer, New York, NY. http://www.stats.ox.ac .uk/pub/MASS4.

Vlček, M., J. Candrák, and R. Kasarda. 2016. Changes of fat-to-protein ratio from start to the mid-lactation and the impact on milk yield. J. Cent. Eur. Agric. 17:1194-1203. https://doi.org/10.5513/ JCEA01/17.4.1830

Zezza, A., G. Federighi, A. A. Kalilou, and P. Hiernaux. 2016. Milking the data. Measuring milk off-take in extensive livestock systems. Experimental evidence from Niger. Food Policy 59:174-186. https: //doi.org/10.1016/j.foodpol.2016.01.005. 


\section{APPENDIX}

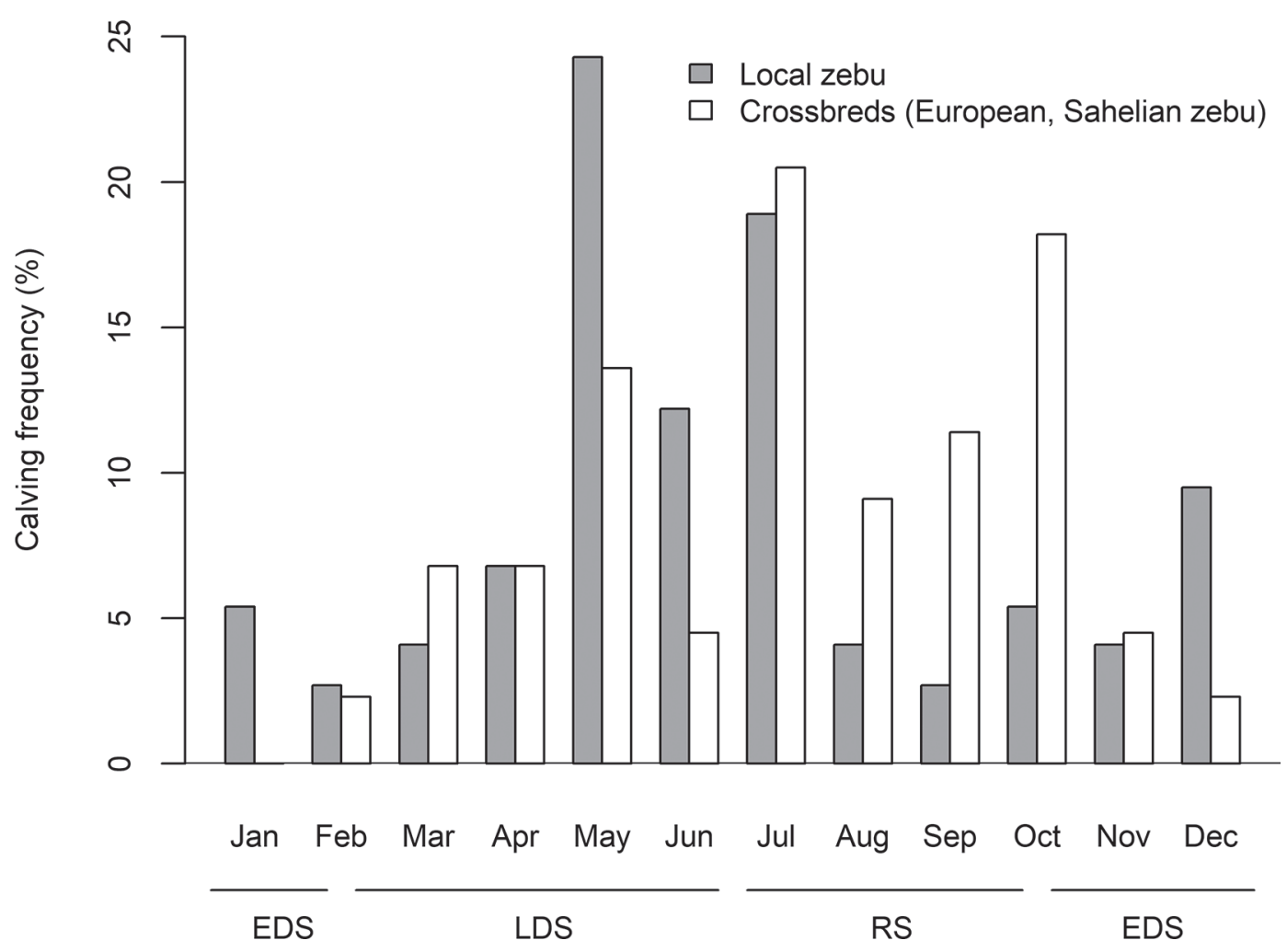

Figure A1. Frequency (\%) of calvings of local zebu ( $\mathrm{n}=74$ observations) and crossbred cows (European $\times$ local zebu, Sahelian zebu $\times$ local zebu; $\mathrm{n}=44$ observations) by month and season. EDS = early dry season; LDS = late dry season; RS = rainy season. 